\title{
Pregnancy, but not dietary octanoic acid supplementation, stimulates the ghrelin-pituitary growth hormone axis in mice
}

\author{
Harleen Kaur1,2, Beverly S Muhlhausler3,7, Pamela Su-Lin Sim³, Amanda J Page2,4, Hui Li2,4, Maria Nunez-Salces2,4, \\ Georgia S Clarke1,2,4, Lili Huang5, Rebecca L Wilson ${ }^{1,2}$, Johannes D Veldhuis ${ }^{6}$, Chen Chen5, Claire T Roberts',2 and \\ Kathryn L Gatford ${ }^{1,2}$ \\ ${ }^{1}$ Robinson Research Institute, The University of Adelaide, Adelaide, Australia \\ 2Adelaide Medical School, The University of Adelaide, Adelaide, Australia \\ ${ }^{3}$ Food and Nutrition Research Group, School of Agriculture, Food and Wine, The University of Adelaide, Adelaide, Australia \\ ${ }^{4}$ Nutrition, Diabetes \& Gut Health, Lifelong Health Theme, South Australian Health and Medical Research Institute (SAHMRI), Adelaide, Australia \\ ${ }^{5}$ School of Biomedical Sciences, University of Queensland, St Lucia, Brisbane, Australia \\ ${ }^{6}$ Endocrine Research Unit, Mayo School of Graduate Medical Education, Center for Translational Science Activities, Mayo Clinic, Rochester, \\ Minnesota, USA \\ ${ }^{7}$ Nutrition and Health Program, Health and Biosecurity Business Unit, Commonwealth Scientific and Industrial Research Organisation, Adelaide, Australia \\ Correspondence should be addressed to K L Gatford: kathy.gatford@adelaide.edu.au
}

\begin{abstract}
Circulating growth hormone $(\mathrm{GH})$ concentrations increase during pregnancy in mice and remain pituitary-derived. Whether abundance or activation of the $\mathrm{GH}$ secretagogue ghrelin increase during pregnancy, or in response to dietary octanoic acid supplementation, is unclear. We therefore measured circulating $\mathrm{GH}$ profiles in late pregnant C57BL/6J mice and in aged-matched non-pregnant females fed with standard laboratory chow supplemented with $5 \%$ octanoic or palmitic (control) acid ( $n=4-13$ /group). Serum total and acyl-ghrelin concentrations, stomach and placenta ghrelin mRNA and protein expression, Pcsk1 (encoding prohormone convertase 1/3) and Mboat4 (membrane bound O-acyl transferase 4) mRNA were determined at zeitgeber (ZT) 13 and ZT23. Total and basal GH secretion were higher in late pregnant than nonpregnant mice $(P<0.001)$, regardless of diet. At ZT13, serum concentrations of total ghrelin $(P=0.004)$, but not acyl-ghrelin, and the density of ghrelin-positive cells in the gastric antrum $(P=0.019)$ were higher, and gastric Mboat4 and Pcsk1 mRNA expression were lower in pregnant than non-pregnant mice at ZT23. In the placenta, ghrelin protein was localised mostly to labyrinthine trophoblast cells. Serum acyl-, but not total, ghrelin was lower at mid-pregnancy than in non-pregnant mice, but not different at early or late pregnancy. In conclusion, dietary supplementation with $5 \%$ octanoic acid did not increase activation of ghrelin in female mice. Our results further suggest that increases in maternal GH secretion throughout murine pregnancy are not due to circulating acylghrelin acting at the pituitary. Nevertheless, time-dependent increased circulating total ghrelin could potentially increase ghrelin action in tissues that express the acylating enzyme and receptor.
\end{abstract}

https://joe.bioscientifica.com https://doi.org/10.1530/JOE-20-0072
(C) 2020 Society for Endocrinology Published by Bioscientifica Ltd. Printed in Great Britain

\author{
Key Words \\ - mouse \\ - pregnancy \\ - octanoic acid \\ - ghrelin \\ - growth hormone
}

Journal of Endocrinology (2020) 245, 327-342 


\section{Introduction}

Successful pregnancy requires substantial maternal physiological adaptations, including increases in food intake, to maintain maternal health and allow optimal growth of the feto-placental unit to term. Growth hormone $(\mathrm{GH})$ is a key endocrine regulator of growth and metabolism in a range of mammalian species and its secretion changes markedly during pregnancy. In humans, placental synthesis of variant $\mathrm{GH}$ in the syncytiotrophoblast increases circulating GH concentrations and progressively suppresses pulsatile pituitary secretion from mid-pregnancy onwards (Eriksson et al. 1989). Although the placentas of most other mammalian species, including rodents, do not produce GH (Papper et al. 2009), circulating GH does increase during pregnancy in the majority of species investigated to date. In contrast to humans, circulating GH profiles remain pulsatile throughout pregnancy in mice and rats (Saunders et al. 1976, El-Kasti et al. 2008, Gatford et al. 2017). In these species, the increase in average circulating GH concentration and secretion reflect elevated basal GH secretion, while the number and amplitude of GH pulses remains unchanged (Saunders et al. 1976, El-Kasti et al. 2008, Gatford et al. 2017). In addition to driving maternal metabolic adaptation to pregnancy, including insulin resistance (Catalano et al. 1991, Newbern \& Freemark 2011, Lager \& Powell 2012, Liao et al. 2016, Teixeira et al. 2019), GH likely promotes fetal growth through other mechanisms. Provided maternal nutrition is adequate, intermittent maternal treatment with exogenous $\mathrm{GH}$ increases fetal growth in non-human species including rats, pigs and sheep (Spencer et al. 1994, Sterle et al. 1995, Harding et al. 1997, Gatford et al. 2000, 2004, de Boo et al . 2008, Tung et al. 2012), likely through enhanced placental growth and/or function (Spencer et al. 1994, Sterle et al. 1995, Harding et al. 1997, Gatford et al. 2000, Tung et al. 2012). Despite the importance of GH during pregnancy in many mammals, the mechanism driving increased maternal GH in non-human species remains less wellknown.

The increases in circulating GH concentration and basal GH secretion in pregnant mice (Gatford et al. 2017) coincide with the formation of the chorioallantoic placenta and initiation of maternal blood flow through the placenta (Pringle \& Roberts 2007). This suggests that placentally-secreted factors are likely to be responsible, either indirectly or directly, for driving the increased pituitary GH secretion during rodent pregnancy.
Ghrelin, a gastric peptide hormone that acts in conjunction with hypothalamic growth hormone-releasing hormone (GHRH) and somatostatin to generate pulsatile GH secretion from the anterior pituitary, is one possible candidate. In mouse stomach, the endoproteolytic processing of the ghrelin molecule from its precursor (proghrelin) into mature ghrelin is facilitated by the enzyme prohormone convertase 1/3 (PC1/3, encoded by proprotein convertase, Pcks1) (Zhu et al. 2006). Ghrelin is secreted in its des-acyl form and requires activation by acylation of the peptide's serine 3 residue with an 8-carbon octanoyl group (Kojima et al. 1999). This modification is mediated by the enzyme membrane bound O-acyl transferase (Mboat4, also known as GOAT) and allows the activated acyl-ghrelin to bind to the GH-secretagogue receptor (GHSR, Kojima et al. 1999, Gutierrez et al. 2008), stimulating GH secretion. Intravenous administration of exogenous acyl-ghrelin induces GH pulses in humans and rodents (Kojima et al. 1999, Arvat et al. 2001), while mice deficient in ghrelin or Mboat 4 have lower amplitude GH pulses than littermate controls (Hassouna et al. 2014, Xie et al. 2015). Acyl-ghrelin, but not des-acyl ghrelin, also acts centrally to stimulate food intake (Nakazato et al. 2001, Neary et al. 2006), and acyl-ghrelin plays an important role in metabolic adaptations to maintain circulating glucose in response to calorie restriction, particularly in pregnancy (Trivedi et al. 2017). Although ghrelin and Mboat4 are predominantly expressed in the stomach (Kojima et al. 1999), ghrelin, Mboat4 and GHSR expression are also detected in the human (Gnanapavan et al. 2002, González-Domínguez et al. 2016) and rodent (Gualillo et al. 2001, Nonoshita et al. 2010) placenta. Furthermore, maternal administration of exogenous acyl-ghrelin promotes fetal growth in rats (Nakahara et al. 2006). This raises the possibility that ghrelin could be synthesised by, and act directly on, the placenta, as well as through central actions, to stimulate maternal GH secretion, food intake and fetal growth.

The potential role of ghrelin in pregnancy is supported by evidence that there are changes in maternal circulating ghrelin during pregnancy in a number of mammalian species. However, the reported changes in circulating total and acyl-ghrelin during pregnancy vary between studies. Total ghrelin concentration has been reported as lower compared to non-pregnant levels in humans and as lower or unchanged in pregnant rats (Gualillo et al. 2001, Shibata et al. 2004, Fuglsang et al. 2005, Tham et al. 2009, Johnson et al. 2019). Conflicting evidence is likewise available regarding changes in 
acyl-ghrelin, with either elevated or lower concentrations during pregnancy in women (Palik et al. 2007, Tham et al . 2009) and elevated during late pregnancy in a single study in rats (Szczepankiewicz et al. 2010). Although responses to exogenous ghrelin demonstrate its functional activity during pregnancy, the role of endogenous ghrelin during pregnancy remains unclear. Pregnant mice lacking the Mboat4 gene, which consequently cannot convert ghrelin to acyl-ghrelin (Trivedi et al. 2015), still undergo a similar increase in GH during late pregnancy (Trivedi et al. 2015), suggesting that acyl-ghrelin is not required to increase GH during pregnancy. However, in this study, GH was only measured in maternal blood collected at post-mortem and, therefore, it is unknown whether the lack of acylghrelin altered the circulating patterns of GH during pregnancy (Trivedi et al. 2015). These pulsatile patterns of circulating GH during pregnancy are important since intermittent, but not continuous, GH administration improves placental function and increases fetal growth in a number of animal species (Clendinnen \& Eayrs 1961, Gargosky et al. 1991, Jørgensen et al. 1991, Spencer et al. 1994).

The finding that increased acylation of ghrelin can be achieved by a nutritional approach (Nishi et al. 2005, Gutierrez et al. 2008, Kirchner et al. 2009) offers great translational potential as an approach to increase circulating GH. Oral supplementation with the C8 medium chain-fatty acid, octanoic acid or with the triglyceride containing this fatty acid, glyceryl trioctanoate, induced octanoylation of ghrelin in the stomach and increased abundance of circulating acylghrelin in mice (Nishi et al. 2005, Gutierrez et al. 2008, Kirchner et al. 2009). Similarly, enteral feeding with octanoic-acid enriched formula increased circulating acyl-ghrelin in humans (Ashitani et al. 2009). Further, dietary supplementation with a medium chain triglyceride mixture containing $65-75 \%$ octanoic acid increased circulating levels of acyl-ghrelin in pigs (Miller et al. 2016).

Therefore, the aims of the present study were: (1) to characterise and compare the GH-ghrelin axis in non-pregnant and pregnant mice and (2) to determine the effect of dietary octanoic acid supplementation on this axis in both pregnant and non-pregnant animals. We hypothesised that the GH-ghrelin axis would be upregulated during pregnancy and that dietary octanoic acid supplementation would increase circulating acylghrelin and GH, and pulsatile GH secretion, in both nonpregnant and pregnant mice.

\section{Materials and methods}

\section{Ethical approval}

Experimental procedures were approved by The University of Adelaide Animal Ethics Committee (studies one and two, M-2016-186) or South Australian Health and Medical Research Institute (SAHMRI) Animal Ethics Committee (study three, SAM395.19) and carried out in accordance with the Australian code of practice for the care and use of animals for scientific purposes (National Health and Medical Research Council of Australia 2013).

\section{Animals and experimental design}

\section{Study one}

Virgin female C57Bl/6J 10-week-old female mice were obtained from the Animal Resource Centre, Perth, and CBAF1 males were obtained from Laboratory Animal Services, The University of Adelaide. All animals were acclimatised to the facility for at least 7 days prior to commencement of cycle tracking, with estrus cycles tracked for at least 8 days prior to mating. All mice were housed at $\sim 23^{\circ} \mathrm{C}$ with $12 \mathrm{~h}$ light: $12 \mathrm{~h}$ darkness cycle (lights on at 06:00 $\mathrm{h}$ or zeitgeber (ZT0), with ad libitum access to water and meat-free rat and mouse diet (14.0 MJ/kg, 20\% protein, Speciality Feeds, Glen Forrest, Australia), except when fed experimental diets as detailed subsequently. Female mice were weighed daily throughout the experiment. Estrus stage in females was classified daily by observation of cell types collected by gently flushing the vagina with $10 \mu \mathrm{L}$ of saline (Caligioni 2009). To generate timed pregnancies, a male was placed in the females' cage overnight when one or both females were in diestrus-to-proestrus transition or proestrus. The presence of a vaginal plug on the following morning was taken as confirmation of successful mating and designated as 0.5 day of pregnancy (GD0.5). Pregnancy was subsequently confirmed by weight gain and at post-mortem.

The experimental diets were based on prior observations that adding $5 \mathrm{mg} / \mathrm{mL}$ octanoic acid to drinking water or feeding a diet supplemented with 5\% glyceryl trioctanoate increased stomach acyl-ghrelin content in mice, while dietary tripalmitate did not alter ghrelin activation (Nishi et al. 2005). The experimental diets were therefore generated by adding $5 \%$ (wt/wt) of either octanoic acid or palmitic acid to ground meat-free rat and mouse diet (Speciality Feeds), which was then re-formed into pellets and baked for $4 \mathrm{~h}$ at $60^{\circ} \mathrm{C}$ prior to feeding. Experimental diets were fed ad libitum throughout 
the remainder of the experiment, commencing at GD0.5 in mated groups and from the same day in age-matched controls, including the day of sampling. To confirm the fatty acid content, samples of each diet were ground, extracted into chloroform and analysed for fatty acid composition as described.

Samples were collected from pregnant mice $(n=8$ palmitic acid diet, $n=7$ octanoic acid diet) at 17.5 days after mating (term is $~ 19.3$ days after mating in this strain (Murray et al. 2010) and from non-pregnant mice ( $n=9$ palmitic acid diet, $n=10$ octanoic acid diet) when mice were in diestrus and between 15.5 and 19.5 days after commencing experimental diets. Additional nonpregnant mice ( $n=2$ palmitic acid diet, $n=3$ octanoic acid diet) did not enter diestrus between 15.5 and 19.5 days after commencing experimental diets and were thus not sampled for $\mathrm{GH}$, since secretion patterns change throughout the estrus cycle (Chen Chen, personal communication). All other samples were collected from these animals. To minimise stress, all females were handled daily for $\sim 5$ min per mouse for $\geq 14$ days before sampling. GH samples were collected from each animal over a continuous 6-h period to allow patterns of GH in the circulation and of GH secretion to be determined. From 13:00 h, ZT7 (lights on at 06:00 h, lights off at 18:00 h, ZT12), 36 sequential tail-tip blood samples (each $2 \mu \mathrm{L}$ ) were collected at 10-min intervals from each mouse, processed and stored at $-80^{\circ} \mathrm{C}$ for later analysis as previously described (Steyn et al. 2011, Gatford et al. 2017). Shortly after collection of the final sample (19:00 h to $19: 30 \mathrm{~h}$ ), mice were terminally anaesthetised by i.p injection of Avertin (2,2,2-tribromoethanol and tertamyl alcohol; Sigma-Aldrich) and 0.5 to $1.0 \mathrm{~mL}$ of venous blood was collected via retro-orbital puncture. Whole blood $(30 \mu \mathrm{L})$ from each individual mouse was spotted onto customised PUFAcoat ${ }^{\mathrm{TM}}$ collection cards and air dried for later analysis of free fatty acids (Liu et al. 2014). The remaining blood was collected into Eppendorf tubes containing 4-(2-aminoethyl) benzenesulphonyl fluoride (AEBSF; at a final concentration of $2 \mathrm{mg}$ AEBSF per $\mathrm{mL}$ whole blood), allowed to clot at room temperature for $30 \mathrm{~min}$ before centrifugation and plasma acidified to a final concentration of $0.05 \mathrm{M} \mathrm{HCl}$ to minimise breakdown of acyl-ghrelin (Delhanty et al. 2015). Following blood collection, mice were humanely killed by cervical dislocation. The uterus was removed from pregnant mice and the stomach was rapidly collected for processing as described. The stomach was opened along the greater curvature and rinsed in saline prior to dissection, along the lesser curvature, into two pieces. Mucosal scrapings from the corpus and antrum, the glandular regions of the stomach, were collected from one half of the stomach, snap-frozen in liquid nitrogen and stored at $-80^{\circ} \mathrm{C}$ until further analysis. For the immunohistochemistry experiments, the other half of the stomach was pinned out flat in $4 \%$ paraformaldehyde dissolved in $0.1 \mathrm{M}$ phosphate buffer (PFA-PB) and rocked at room temperature for $3 \mathrm{~h}$ before cryoprotection in 30\% sucrose-PB solution overnight. The stomachs were then embedded in optimal cutting temperature compound (Tissue-Tek, ProSciTech, Queensland, Australia), frozen and stored at $-80^{\circ} \mathrm{C}$ until sectioning (Li et al. 2018). The numbers of implantations, fetuses and resorption sites were counted and each fetus and placenta was dissected and weighed. Placentas were alternately snap-frozen in liquid nitrogen or fixed for histological analysis as described. Complete suppression of GH secretion was observed in two pregnant mice, who had normal litter size and fetal weights at post-mortem. Data for these animals were excluded from all analyses, because a loss of GH secretion occurs acutely in stressed mice (Steyn et al. 2012) and these two animals were therefore not considered to reflect the normal physiology of pregnancy.

\section{Study two}

In study one, plasma samples were collected from animals at the completion of GH sampling, when most animals had not eaten. Upon analysis, we found no difference in the circulating plasma acyl-ghrelin concentrations between groups. Given the rapid turnover of acyl-ghrelin in circulation (Delhanty et al. 2015), we considered it possible that any effects of diet on ghrelin production and release may only have been evident close to the time of feeding. Therefore, in order to determine whether there was an increase in basal circulating plasma acylghrelin levels in mice that had undisturbed access to food overnight, we conducted a second study, with the same interventions, but with samples collected late in the active feeding period (darkness phase) for mice (Bake et al. 2014) and without serial sampling for GH, to minimise disruption to feeding. Animal management, breeding and diets were as described for study one. Animals were humanely killed at 07:30 $\mathrm{h}$ to 08:00 $\mathrm{h}$ (lights on at 09:00 h, lights off at 21:00 h), and blood and tissue samples were collected as described previously.

\section{Study three}

Since circulating ghrelin was not consistently different between non- and late-pregnant mice in the first two studies, we collected plasma from a third cohort of mice 
to assess changes in ghrelin abundance throughout pregnancy. Mice were sampled shortly after lights on, at a time when they have recently eaten (Kentish et al. 2013). Female C57Bl/6J 10-12 week-old female mice were obtained from SAHMRI Bioresources. All mice were housed at $\sim 22^{\circ} \mathrm{C}$ with $12 \mathrm{~h}$ light: $12 \mathrm{~h}$ darkness cycle (lights on at 07:00 h, with ad libitum access to water and standard rodent diet (18.6\% protein, $6.2 \%$ fat, $44.2 \%$ carbohydrate, Teklad standard diet, Envigo, Cambridgeshire, United Kingdom). For timed mating, female mice were pairhoused with a C57BL/6J male at 17:00 h, and pregnancy was confirmed by the presence of a vaginal plug at 07:00 $\mathrm{h}$ (assigned as day 0.5 of pregnancy) before being returned to individual cages. Plugged females were randomly assigned to either early (6.5 days, $n=8)$, mid (12.5 days, $n=8$ ) or late (18.5 days, $n=8)$ stage pregnancy end points. Agematched females that were not housed with a male for mating were used as non-pregnant controls $(n=8)$. Mice were anaesthetised at ZT0-ZT1 by isoflurane inhalation (5\% in oxygen) and venous blood was collected from the inferior vena cava and processed as described to obtain plasma for ghrelin assays. Mice were then humanely killed via decapitation.

\section{Analysis of fatty acids in feed and blood}

The fatty acid composition of blood and feed samples was assessed as previously described (Liu et al. 2014, Kanakri et al. 2017). Briefly, whole dried blood spots from the PUFAcoat ${ }^{\mathrm{TM}}$ cards and extracted feed samples were trans-esterified with $2 \mathrm{~mL}$ of $1 \% \mathrm{H}_{2} \mathrm{SO}_{4}$ in methanol at $70^{\circ} \mathrm{C}$ for $3 \mathrm{~h}$. After adding distilled water and heptane to the vial, the samples were shaken using a vortex. Samples were then left standing and the top heptane layer containing fatty acid methyl esters was extracted and analysed using gas chromatography (Liu et al. 2014). Abundance of each fatty acid is expressed as a percentage of total fatty acids in the sample.

\section{Hormone analyses}

Serum concentrations of acyl-ghrelin and total ghrelin were determined by commercial enzyme-linked immunoabsorbent assay (ELISA) kits (EZRGRA-90K, Rat/mouse Ghrelin (Active) ELISA and EZRGRT-91K, Rat/mouse Ghrelin (Total) ELISA, respectively; R\&D Systems), in accordance with the manufacturer's instructions. A single ELISA plate was used to measure all samples from each study. Within-assay coefficients of variation were each $<10 \%$ (study 1: total ghrelin: $4.1 \%$, acyl-ghrelin: 7.4\%; study 2: total ghrelin: 5.8\%, acyl-ghrelin: 3.8\%).
Analysis for $\mathrm{GH}$ was performed using an in-house mouse GH ELISA as described and validated previously (Steyn et al. 2011). Within- and between-assay coefficients of variation were $2.0 \%$ and $16.8 \%$, respectively, for a mouse plasma QC sample containing $27.7 \mathrm{ng} / \mathrm{mL}(n=16$ assays). All samples from a single mouse (serial samples for analysis of secretion pattern) were analysed on the same ELISA plate. Kinetics and secretory patterns of pulsatile $\mathrm{GH}$ secretion were determined by deconvolution analysis following parameters established previously for $\mathrm{GH}$ secretion in mouse (Steyn et al. 2011, 2012). The orderliness and regularity of serial GH serum concentrations were calculated by approximate entropy (ApEn) analysis as described previously; a higher absolute ApEn denotes greater irregularity and indicates a loss in stability of feedback of GH regulation (Veldhuis et al. 2001).

\section{Ghrelin and Mboat4 gene expression in stomach and placenta}

Total RNA from snap-frozen placenta and gastric mucosal scrapings was extracted using PureLink RNA Mini Kit (12183018A; Invitrogen) and quantified using a NanoDrop spectrophotometer (Thermo Fisher Scientific). Quantitative real-time PCR reactions (qPCR) were performed using a 7500 Fast Real-time PCR System (Life Technologies) and Express One-Step SuperScript qRT-PCR Kit (11781-200, Invitrogen). Predesigned Taqman gene expression assays (4331182, Life Technologies) that target Ghrelin (Mm00445450_m1), Mboat4 (Mm01200389_m1) and Pcsk1 (encodes for PC 1/3; Mm00479023_m1) were used. B2m (Mm00437762_m1), Hprt (Mm01545399_m1) and Ppia (Mm02342429_g1) with an expression stability value of 0.035 were used as reference genes for the gastric mucosa, while Polr2a (Mm00839502_m1) and Ubc (Mm01198158_m1) were identified as suitable reference genes in the mouse placenta (Solano et al. 2016). qPCR reactions were carried out under the following conditions: RT, $50^{\circ} \mathrm{C}$ for $15 \mathrm{~min}$; initial PCR activation, $95^{\circ} \mathrm{C}$ for $20 \mathrm{~s}$; PCR cycles $95^{\circ} \mathrm{C}$ for $3 \mathrm{~s}, 60^{\circ} \mathrm{C}$ for $30 \mathrm{~s}$ repeated for 40 cycles. Each assay was run in triplicate. Control PCRs were carried out substituting RNase-free water for template RNA. Relative RNA levels were calculated using the delta CT method as described previously (Li et al. 2018).

\section{Immunohistochemistry and histology}

\section{Stomach ghrelin localisation}

Stomach tissue was sectioned $(10 \mu \mathrm{m})$, air dried at RT before being rinsed in PBS $+0.2 \%$ Triton $\mathrm{X}-100$ 
(PBS-TX; Sigma-Aldrich) and blocked with 10\% donkey serum at room temperature. To detect ghrelin immunoreactivity, sections were then incubated with rabbit-anti-ghrelin primary antibody (1 in 800 dilution in PBS-TX; Abcam Cat\# ab129383, RRID:AB_11159267ab129383, Abcam) for $20 \mathrm{~h}$ at $4^{\circ} \mathrm{C}$ and donkey-anti-rabbit 488 secondary antibody (1 in 200 in PBS-TX, Cat\# A-21206, RRID:AB_2535792 Thermo Fisher Scientific) for $1 \mathrm{~h}$ at RT. The slides were mounted using ProLong Antifade (Life Technologies). Slides where primary antibody was omitted showed no labeling and served as negative controls. Slide sections were visualised using an epifluorescence microscope (BX-51, Olympus) equipped with filters for Alexa Fluor ${ }^{\circledR} 488$, with images acquired using a CoolSnapfx monochrome digital camera (Roper Scientific, Tuscon, AZ, USA). Ghrelinpositive cells were counted manually on images taken at $10 \times$ magnification by two people blind to treatment. Ten stomach tissue sections were randomly chosen from each mouse. In each section, ghrelin-positive cells were counted in an area of $400 \times 400 \mu \mathrm{m}$ in both proximal corpus and distal antrum. The number of ghrelin-positive cells in corpus or antrum from each mouse was averaged from the ten selected sections.

\section{Placental morphology}

Histological analyses were performed on two placentae from each dam (palmitic acid $n=14$ placentas, octanoic acid $n=12$ placentas). One dam from the palmitic acid group was excluded from this analysis due to a small litter size (a single fetus); however, the placenta was collected and frozen for gene expression analysis. Bisected placentae were fixed in 4\% paraformaldehyde (PFA), washed in $1 \mathrm{X}$ PBS over $48 \mathrm{~h}$ and stored in 70\% ethanol prior to being paraffin embedded. Full-faced placental sections cut to $5 \mu \mathrm{m}$ thickness were stained with Masson's Trichrome following standard protocols (Roberts et al. 2003). Areas of junctional zone and placental labyrinth for each placental section were visualised and measured with NDP.view 2 software (Hamamatsu Photonics, Shizuoka, Japan). Total cross-sectional area and the proportion of junctional zone to placental labyrinth were calculated.

\section{Placental ghrelin localisation}

Full-faced sections cut to $5 \mu \mathrm{m}$ thickness were deparaffinised and rehydrated, using the same placentas as mentioned previously (palmitic acid $n=14$ placentas, octanoic acid $n=12$ placentas). Antigen retrieval was performed by microwaving slides in citrate buffer $(0.2 \%$ citric acid in distilled water) for $10 \mathrm{~min}$ at $150 \mathrm{~W}$.
In order to quench endogenous peroxidase, sections were incubated in $3 \% \mathrm{H}_{2} \mathrm{O}_{2}$ in $1 \times$ PBS for $10 \mathrm{~min}$. Non-specific binding was blocked by incubation with $10 \%$ goat serum in 1× PBS for $30 \mathrm{~min}$ before addition of rabbit anti-ghrelin antibody (1 in 250 dilution, Abcam Cat\# ab129383, RRID:AB_11159267ab129383) and incubated overnight at RT. Bound antibody was detected using biotinylated goat anti-rabbit IgG (1 in 200 dilution, Agilent Cat\# E0432, RRID:AB_2313609,DAKO) for $1 \mathrm{~h}$, followed by streptavidinconjugated horseradish peroxidase (1 in 500 dilution, Cat\# P0397, DAKO) for $1 \mathrm{~h}$, both at RT. Immunolabelling was visualised by incubating sections with diaminobenzidine (Cat\# K346811-2, DAKO) and by counterstaining with hematoxylin before mounting in DPX (Sigma-Aldrich). Areas of ghrelin staining were visualised with NDP.view 2 software (Hamamatsu Photonics).

\section{Statistical analyses}

For studies one and two, effects of diet (palmitic acid supplemented cf. octanoic acid supplemented) and pregnancy status (non-pregnant cf. pregnant) on maternal outcomes were analysed by two-way ANOVA. For study three, effects of pregnancy stage (non-, early-, mid- and late-pregnant) were analysed by one-way ANOVA. Where outcomes differed between pregnancy stages, post-hoc analyses were performed using the Bonferroni correction. Effects of diet on fetal and placental outcomes was analysed using repeated measures ANOVA, treating each fetus or placenta as a repeated measure on the dam. GH secretion data were natural log-transformed to achieve equal variances before analysis. Data are presented as mean \pm S.E.M. and $P<0.05$ was considered statistically significant.

\section{Results}

Pregnancy outcomes were unaffected by maternal diet

Maternal weight gain during the study, body and liver weights at post-mortem (Table 1) and absolute and relative organ weights (liver, kidneys and spleen, data not shown) were higher in pregnant than non-pregnant mice and unaffected by diet. Pregnancy outcomes including litter size, fetal weight and placental gross structure were also unaffected by maternal diet (Table 1).

\section{Circulating fatty acid profiles were altered by diet and pregnancy}

As expected, the content of C16:0 (palmitic acid) was higher in the palmitic acid-supplemented feed 
Table 1 Maternal and pregnancy characteristics (study one ZT13).

\begin{tabular}{|c|c|c|c|c|c|c|c|}
\hline & \multicolumn{2}{|c|}{ Non-pregnant } & \multicolumn{2}{|c|}{ Pregnant } & \multicolumn{3}{|c|}{ P value } \\
\hline & Palmitic acid & Octanoic acid & Palmitic acid & Octanoic acid & Diet & Pregnancy & $\mathrm{D} * \mathrm{P}$ \\
\hline Number of dams & 11 & 13 & 8 & 6 & & & \\
\hline Final body weight (g) & $21.3 \pm 0.1$ & $21.9 \pm 0.3$ & $34.5 \pm 1.3$ & $34.0 \pm 1.5$ & 0.953 & $<0.001$ & 0.542 \\
\hline Weight gain $(\mathrm{g} / \mathrm{d})$ & $0.05 \pm 0.01$ & $0.05 \pm 0.02$ & $0.83 \pm 0.07$ & $0.78 \pm 0.10$ & 0.488 & $<0.001$ & 0.593 \\
\hline Liver (g) & $0.75 \pm 0.03$ & $0.76 \pm 0.02$ & $1.30 \pm 0.08$ & $1.20 \pm 0.16$ & 0.550 & $<0.001$ & 0.431 \\
\hline Liver (\% of body weight) & $2.5 \pm 0.5$ & $3.2 \pm 0.3$ & $3.8 \pm 0.2$ & $3.6 \pm 0.6$ & 0.563 & 0.073 & 0.306 \\
\hline Litter size & & & $6.4 \pm 0.8$ & $7.3 \pm 0.8$ & 0.432 & & \\
\hline Average fetal weight (g) & & & $1.2 \pm 0.1$ & $1.1 \pm 0.1$ & 0.626 & & \\
\hline Average placental weight (g) & & & $0.1 \pm 0.1$ & $0.1 \pm 0.1$ & 0.276 & & \\
\hline Average junctional zone area $\left(\mathrm{mm}^{2}\right)$ & & & $2.5 \pm 0.2$ & $2.5 \pm 0.1$ & 0.938 & & \\
\hline Average labyrinth zone area $\left(\mathrm{mm}^{2}\right)$ & & & $5.2 \pm 0.2$ & $4.7 \pm 0.2$ & 0.158 & & \\
\hline
\end{tabular}

Maternal data were analysed using two-way ANOVA, and data for fetal outcomes were analysed using one-way ANOVA. Data are presented as mean \pm S.E.M. $D * P$, diet*pregnancy interaction; FA, fatty acid.

( $4.1 \mathrm{~g} / 100 \mathrm{~g}$ feed) than in the octanoic acid-supplemented feed $(0.5 \mathrm{~g} / 100 \mathrm{~g}$ feed $)$. Similarly, the content of C8:0 (octanoic acid) was higher in the octanoic acidsupplemented feed $(1.5 \mathrm{~g} / 100 \mathrm{~g}$ feed) than in the palmitic acid-supplemented feed $(0.07 \mathrm{~g} / 100 \mathrm{~g}$ feed $)$.

\section{Study one}

In mice sampled at ZT13, total saturated fatty acid levels were higher in mice fed the palmitic acid than the octanoic acid diet $(P=0.014)$ and higher in pregnant than non-pregnant mice $(P<0.001$, Table 2$)$. Conversely, total monounsaturated fatty acid levels were higher in the blood of mice fed the octanoic acid diet $(P=0.006)$ and in pregnant compared to non-pregnant mice $(P=0.046$, Table 2). Octanoic acid was undetectable in blood, regardless of diet or pregnancy status (data not shown). Circulating palmitic acid (C16:0) comprised a higher percentage of total lipids in mice fed the palmitic acid diet, compared to those fed an octanoic acid diet $(P<0.001)$, and were also higher in pregnant than non-pregnant mice overall $(P<0.001$, Table 2$)$.

\section{Study two}

In mice sampled at ZT23, effects of diet on total saturated fatty acids differed between non-pregnant and pregnant groups (interaction $P=0.022$, Table 2). Thus, in mice fed the palmitic acid-supplemented diet, the concentration of total saturated fatty acids was similar between non-pregnant and pregnant mice. However, within mice fed the octanoic acid-supplemented diet, the concentration of total saturated fatty acids was $7 \%$ higher in pregnant than non-pregnant mice. Circulating total saturated fatty acid concentrations did not differ between diets within either non-pregnant or pregnant groups. Total trans-esterified and monounsaturated fatty acid concentrations were similar between groups $(P>0.05$, Table 2$)$.

\section{Circulating GH was higher in pregnant than non-pregnant mice but was unaffected by diet}

Circulating GH was pulsatile in all mice and mean plasma GH concentrations increased during pregnancy (study one, Fig. 1 and Table 3). Total and basal GH secretion rates were significantly higher in pregnant mice $(P<0.001$, Table 3) compared to non-pregnant mice, irrespective of diet. The irregularity of GH pulses (approximate entropy; $P=0.033)$ and mode of secretion $(P=0.001)$ were also higher in pregnant mice compared to non-pregnant mice and unaffected by diet (Table 3). Pulse frequency, mass of GH released per burst and pulsatile GH secretion rate were similar between dietary groups and between pregnant and non-pregnant animals (Table 3).

\section{Total but not acyl-ghrelin is higher in pregnant than non-pregnant mice, depending on time of day}

In mice sampled at ZT13 (study one), serum total ghrelin levels were significantly higher in pregnant than nonpregnant mice ( $P=0.004$, Fig. 2) and were unaffected by diet, while serum acyl-ghrelin concentrations were similar irrespective of diet or pregnancy status. In mice sampled at ZT23 (study two), total and acyl-ghrelin levels in mice were similar between dietary groups and between pregnant and non-pregnant animals (Fig. 2).

When assessing changes in ghrelin abundance across pregnancy (study three), serum total ghrelin did not differ between pregnancy stages $(P=0.059$, Fig. 3A). In contrast, serum acyl-ghrelin concentrations changed with pregnancy stage $(P=0.008$, Fig. 3B). 
Table 2 Circulating maternal fatty acid concentrations.

\begin{tabular}{l}
\hline \\
\hline Study one \\
$n$ animals \\
Total saturated FA (\% of total lipids) \\
$16: 0$ ( $\%$ of total lipids) \\
Total trans-esterified FA \\
(\% of total lipids) \\
Total monosaturated FA \\
(\% of total lipids) \\
Study two \\
$n$ animals \\
Total saturated FA (\% of total lipids) \\
$16: 0$ ( $\%$ of total lipids) \\
Total trans-esterified FA \\
(\% of total lipids) \\
Total monosaturated FA \\
(\% of total lipids)
\end{tabular}

\section{Non-pregnant \\ Palmitic acid Octanoic acid}

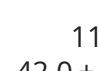

$42.0 \pm 0.2$

$24.7 \pm 0.3$

$0.2 \pm 0.1$

$16.2 \pm 0.3$

13

$44.3 \pm 0.3$

$28.2 \pm 0.2$

$0.3 \pm 0.02$

$14.9 \pm 0.6$

13

$40.6 \pm 0.4$

$22.1 \pm 0.2$

$0.2 \pm 0.1$

$17.8 \pm 0.2$

9

$43.4 \pm 0.5$

$25.6 \pm 0.4$

$0.2 \pm 0.02$

$15.1 \pm 0.2$

\section{Pregnant \\ Palmitic acid Octanoic acid}

8

$44.1 \pm 0.5$

$26.4 \pm 0.3$

$0.2 \pm 0.1$

$17.5 \pm 0.5$

\section{$17.5 \pm 0.5$}

$$
5
$$

$45.1 \pm 0.5$

$28.3 \pm 0.2$

$0.3 \pm 0.03$

$14.4+0.4$

6
$43.3 \pm 0.5$
$24.3 \pm 0.3$
$0.2 \pm 0.1$
$17.9 \pm 0.3$

0.014
$<0.001$

0.674

0.006

$<0.001$

$<0.001$

0.978

0.046

0.092 Fatty acids were measured by GCMS in blood collected from non-pregnant and pregnant mice, fed chow supplemented with either $5 \%$ palmitic acid or
$5 \%$ octanoic acid. Mice in study one were sampled between 1 and $2 \mathrm{~h}$ after lights off, and mice in study two were sampled between 1 and $0 \mathrm{~h}$ before lights on, at the end of the natural feeding period. Data were analysed by two-way ANOVA and are presented as mean \pm S.E.M. $D * P$, diet* pregnancy interaction; FA, fatty acids.

Acyl-ghrelin concentrations were lower in mid-pregnant compared to non-pregnant mice $(P=0.007)$ and did not differ between other pregnancy stages (Fig. 3B).

\section{Stomach and placental ghrelin expression may explain higher total but not acyl-ghrelin in pregnancy}

Gastric ghrelin, Mboat4 and Pcsk1 mRNA levels were similar in all groups at ZT13 (study one, Table 4). Gastric ghrelin mRNA expression was unaffected by pregnancy or diet at ZT23 (study two, Table 4). However, the gastric mRNA expression of Mboat4 and Pcsk1 was lower in pregnant compared to non-pregnant mice at ZT23 (Table 4).

At ZT13 (study one), the effects of pregnancy on the density of ghrelin-positive cells in the corpus region of the stomach differed between diets (interaction, $P=0.003$, Fig. 4C). In mice fed the palmitic acid diet, the density of ghrelin-positive cells in the stomach corpus was higher in pregnant than non-pregnant mice $(P<0.001$, Fig. 4$)$. Pregnancy status did not affect the density of ghrelinpositive cells in the corpus of mice fed the octanoic acid diet. In pregnant mice, the density of ghrelin-positive cells in the corpus was higher in mice fed the palmitic acid compared to mice fed the octanoic acid diet $(P=0.012$, Fig. 4). There was no effect of diet on the density of ghrelin-positive cells in the corpus in non-pregnant mice. In the antrum region, the density of ghrelin-positive cells was higher in pregnant mice than non-pregnant mice $(P=0.019)$, irrespective of diet (Fig. 4E).
(C) 2020 Society for Endocrinology Published by Bioscientifica Ltd.
Printed in Great Britain
At ZT23 (study two), the density of ghrelin-positive cells in the corpus region was higher in pregnant mice than non-pregnant mice $(P=0.023)$, irrespective of diet (Fig. 4D). However, the density of ghrelin-positive cells in the antrum region of the stomach at this sampling time was similar in all groups (Fig. 4F).

Placental ghrelin and Mboat4 mRNA levels were measured in pregnant animals and were unaffected by diet in both studies (Table 5). In the placenta, cytoplasmic ghrelin immunostaining was mostly localised to labyrinthine trophoblast and nuclear immunostaining was present in both labyrinth and junctional zones (Fig. 5). Localisation was unaffected by diet.

\section{Discussion}

In the present study, circulating basal and total GH, as well as total, but not acyl, ghrelin concentrations were significantly higher in pregnant compared to nonpregnant mice. Contrary to our hypothesis, dietary supplementation with octanoic acid did not increase acyl-ghrelin, circulating GH concentration or pulsatile GH secretion in either pregnant or non-pregnant mice.

The increased circulating levels of GH we observed during late pregnancy are consistent with previous studies in mice (Gatford et al. 2017) as well as rats (Saunders et al. 1976, El-Kasti et al. 2008). This further confirms 

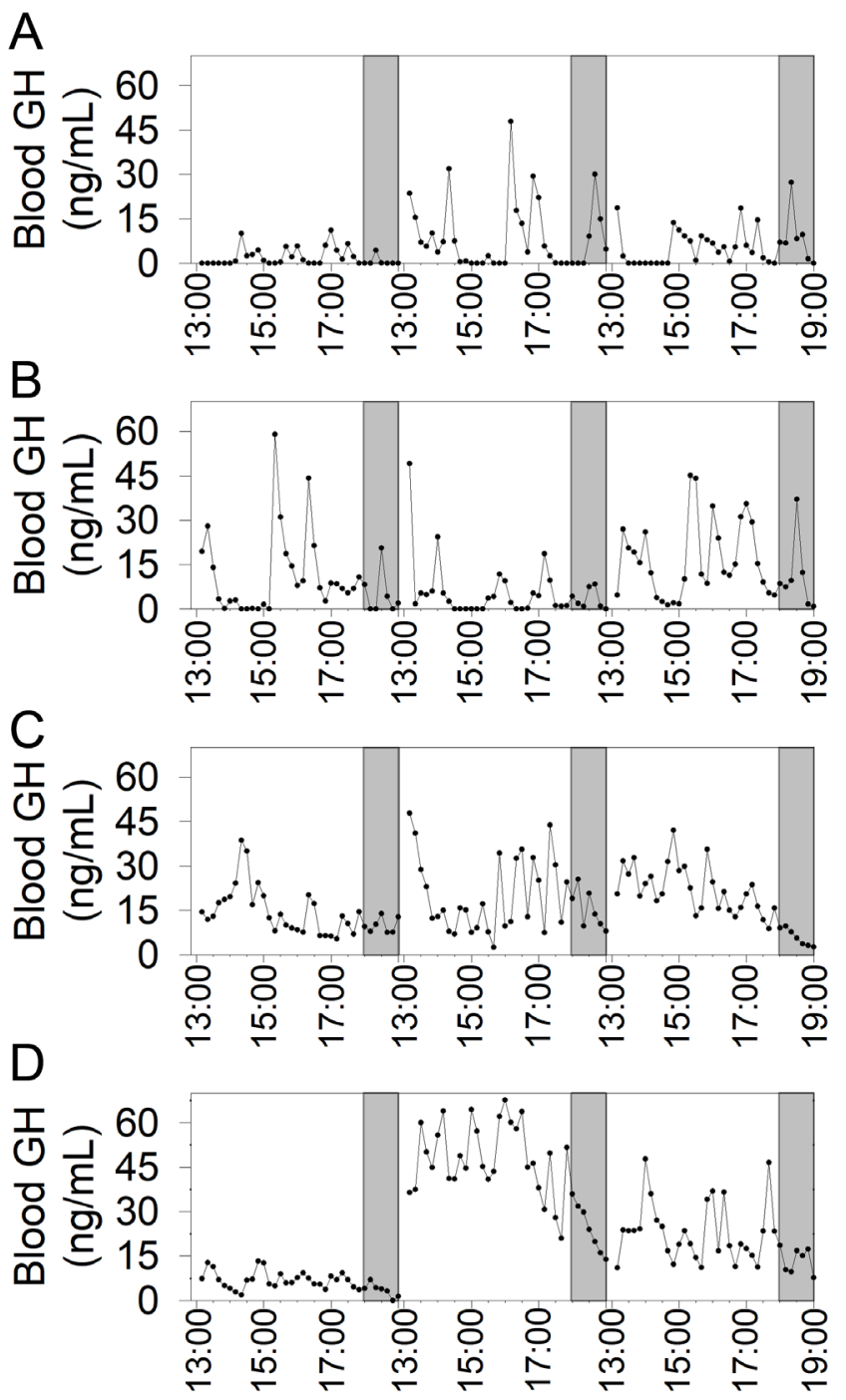

Figure 1

Representative circulating GH profiles in non-pregnant females fed palmitic acid diet; $n=7$ (A) or octanoic acid diet; $n=10$ (B), in mice at GD17.5 or age-matched diestrus controls days of eating experimental diets and in pregnant mice fed palmitic acid diet; $n=8$ (C) or octanoic acid diet; $n=4$ (D) at GD17.5. Shading indicates darkness period.

that maternal GH is elevated in multiple species during pregnancy (Saunders et al. 1976, Eriksson et al. 1989, El-Kasti et al. 2008, Gatford et al. 2017) despite the lack of a placentally-expressed GH variant gene in rodents and most other non-primate species (Papper et al. 2009). Interestingly, GH was elevated in pregnant mice despite the fact that maternal acyl-ghrelin levels were similar in late pregnant and non-pregnant mice and actually lower at mid-pregnancy than in non-pregnant females. These observations are consistent with the findings of Trivedi and colleagues, who demonstrated that circulating GH, measured in single samples at post-mortem, was similarly higher in late pregnant than non-pregnant animals in

(c) 2020 Society for Endocrinology Published by Bioscientifica Ltd. Printed in Great Britain both Mboat4-knockout and WT mice (Trivedi et al. 2015). Together, these findings imply that endogenous circulating acyl-ghrelin is not an important regulator of changes in GH during pregnancy.

Total serum ghrelin concentrations were higher in pregnant than in non-pregnant mice; however, this was only observed in mice that were sampled at the end of the light phase (study one) and not in those sampled at the end of the darkness phase (study two) or early in the light phase (study three). Ghrelin secretion undergoes a pre-prandial increase and a postprandial decline in humans, reflecting its function in stimulating hunger and initiation of meals (Cummings et al. 2001, Tschöp et al. 2001). Besides the stimulation of food intake, ghrelin decreases energy expenditure in rodents and promotes the storage of fatty acids in adipocytes (Tschöp et al. 2000, Mano-Otagiri et al. 2009). The difference in effects of pregnancy on total ghrelin abundance in the light and darkness phases might therefore reflect greater diurnal ghrelin variation in pregnancy, possible due to greater nutrient demand and appetite drive (Ladyman et al. 2010). Consistent with food intake patterns in nonpregnant female and male mice (Yanagihara et al. 2006, Kentish et al. 2016), the majority of food intake occurs during the darkness phase in pregnant mice (Ladyman et al. 2018). Lower acyl-ghrelin concentrations in fed mice at mid-pregnancy (study three) might be a consequence of increasing food intake during pregnancy (Ladyman et al. 2018), since postprandial suppression of plasma ghrelin is proportional to the amount of calories ingested (Callahan et al. 2004). Additional studies are needed to characterise the circadian rhythm in ghrelin and determine whether these change in pregnancy.

The higher circulating total ghrelin concentrations in pregnant than in non-pregnant mice in study one might be explained by greater ghrelin production in the stomach, as well as potentially by placental production. Specific cells in the stomach, particularly X/A-like enteroendocrine cells, are the main site of ghrelin production and acylation in non-pregnant animals (Date et al. 2000), and in male mice preproghrelin mRNA expression is substantially higher in the stomach than in other tissues (Yang et al. 2008). Although ghrelin mRNA expression was detected in placenta, its abundance was $>1000$-fold lower than in stomach, suggesting that its contribution to circulating ghrelin is relatively minor, although abundant ghrelin was evident in placentas stained for ghrelin protein. Gene expression of ghrelin in the stomach was not different in pregnant and non-pregnant mice in either study, consistent with similar stomach, hypothalamic and 
Table 3 Circulating maternal growth hormone $(\mathrm{GH})$ and parameters of pulsatile $\mathrm{GH}$ secretion following deconvolution and approximate entropy (ApEn) analysis.

\begin{tabular}{|c|c|c|}
\hline & \multicolumn{2}{|c|}{ Non-pregnant } \\
\hline & Palmitic acid & Octanoic acid \\
\hline$n$ samples & 7 & 10 \\
\hline Mean circulating $\mathrm{GH}(\mathrm{ng} / \mathrm{mL})$ & $3.9 \pm 1.0$ & $6.1 \pm 1.3$ \\
\hline $\begin{array}{l}\text { Total GH secretion rate } \\
(\mathrm{ng} / \mathrm{mL} 6 \mathrm{~h})\end{array}$ & $169.2 \pm 43.0$ & $247.7 \pm 58.3$ \\
\hline $\begin{array}{l}\text { Basal GH secretion rate } \\
(\mathrm{ng} / \mathrm{mL} 6 \mathrm{~h})\end{array}$ & $18.0 \pm 11.3$ & $68.6 \pm 24.8$ \\
\hline Interval between bursts & $19.9 \pm 10.0$ & $24.3 \pm 8.0$ \\
\hline Number of GH pulses/6 h & $4.1 \pm 0.8$ & $4.2 \pm 0.6$ \\
\hline Mode of secretory bursts (min) & $15.0 \pm 2.0$ & $11.3 \pm 0.5$ \\
\hline ApEn & $0.8 \pm 0.1$ & $0.9 \pm 0.04$ \\
\hline $\begin{array}{l}\text { Mass of GH secreted/burst } \\
(\mathrm{ng} / \mathrm{mL})\end{array}$ & $34.5 \pm 8.5$ & $47.8 \pm 9.9$ \\
\hline $\begin{array}{l}\text { Pulsatile GH secretion rate } \\
\text { (ng/mL } 6 \text { h) }\end{array}$ & $151.2 \pm 44.7$ & $179.1 \pm 40.0$ \\
\hline
\end{tabular}

\begin{tabular}{|c|c|c|c|c|}
\hline \multicolumn{2}{|c|}{ Pregnant } & \multicolumn{3}{|c|}{$P$ value } \\
\hline Palmitic acid & Octanoic acid & Diet & Pregnancy & $D * P$ \\
\hline 8 & 4 & & & \\
\hline $11.4 \pm 2.7$ & $18.5 \pm 9.2$ & 0.155 & 0.004 & 0.433 \\
\hline $491.6 \pm 118.1$ & $819.1 \pm 409.1$ & 0.159 & $<0.001$ & 0.382 \\
\hline $312.2 \pm 85.4$ & $404.6 \pm 187.3$ & 0.344 & $<0.001$ & 0.780 \\
\hline $26.0 \pm 6.7$ & $28.0 \pm 10.3$ & 0.343 & 0.151 & 0.724 \\
\hline $5.4 \pm 0.7$ & $5.8 \pm 0.9$ & 0.773 & 0.073 & 0.832 \\
\hline $7.6 \pm 1.2$ & $8.7 \pm 1.4$ & 0.353 & 0.001 & 0.096 \\
\hline $1.0 \pm 0.1$ & $1.0 \pm 0.1$ & 0.573 & 0.033 & 0.528 \\
\hline $39.3 \pm 11.0$ & $62.8 \pm 31.0$ & 0.187 & 0.472 & 0.709 \\
\hline $179.4 \pm 40.5$ & $414.5 \pm 262.2$ & 0.130 & 0.130 & 0.230 \\
\hline
\end{tabular}

Data were analysed by two-way ANOVA and are presented as mean \pm S.E.M. $D * P$, diet*pregnancy interaction.

pituitary ghrelin expression in pregnant and non-pregnant mice reported previously (Trivedi et al. 2017). However, the 1.5-fold greater density of ghrelin-positive cells in the stomach antrum of pregnant than non-pregnant mice sampled at ZT13 (study one) suggests a greater capacity to secrete ghrelin, although this was not seen at ZT23 (study two). We saw a similar pattern for the stomach corpus, with greater ghrelin-positive cell density in pregnant than non-pregnant mice at ZT23, although at ZT13 the effect of pregnancy was only significant within the subset fed the palmitic acid diet. The discrepancy between ghrelin gene expression levels and number of ghrelin-positive
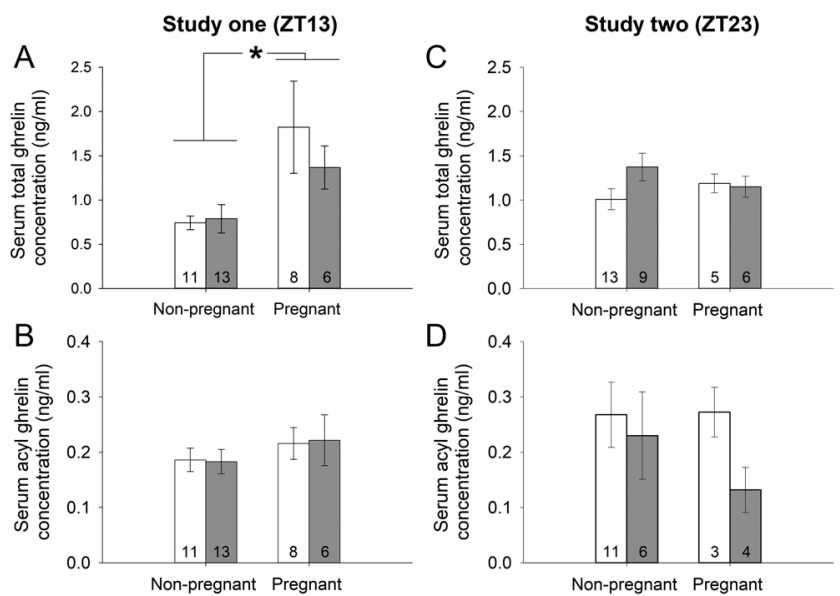

Figure 2

Circulating maternal serum total ( $A$ and $C$ ) and acyl ( $B$ and $D$ ) ghrelin in non-pregnant and pregnant mice fed palmitic acid diet (white bars) or octanoic acid diet (grey bars), sampled at ZT13 (study one, A and B) or ZT23 (study two, C and D), in mice at GD17.5 or age-matched controls. Data were analysed by two-way ANOVA and are presented as mean \pm S.E.M. Animal numbers are indicated by numerals within bars. cells in the stomach may be because gene expression was measured from the entire gastric mucosa, whereas ghrelinpositive cell count was carried out in specific sections of the stomach. Given the variability within groups and relatively low sample size, we suggest that this is probably

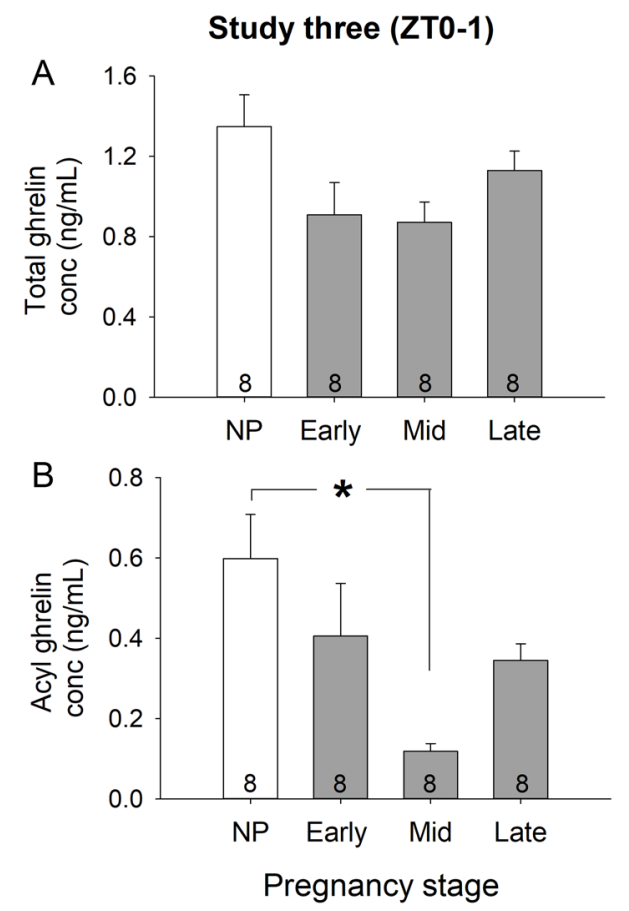

Figure 3

Circulating maternal plasma total (A) and acyl (B) ghrelin throughout pregnancy in non-pregnant (white bars), early, mid and late pregnant (grey bars) mice sampled at ZTO-1 (study three). Data were analysed by one-way ANOVA and are presented as mean \pm S.E.M. Animal numbers are indicated by numerals within bars.
(C) 2020 Society for Endocrinology Published by Bioscientifica Ltd. Printed in Great Britain 


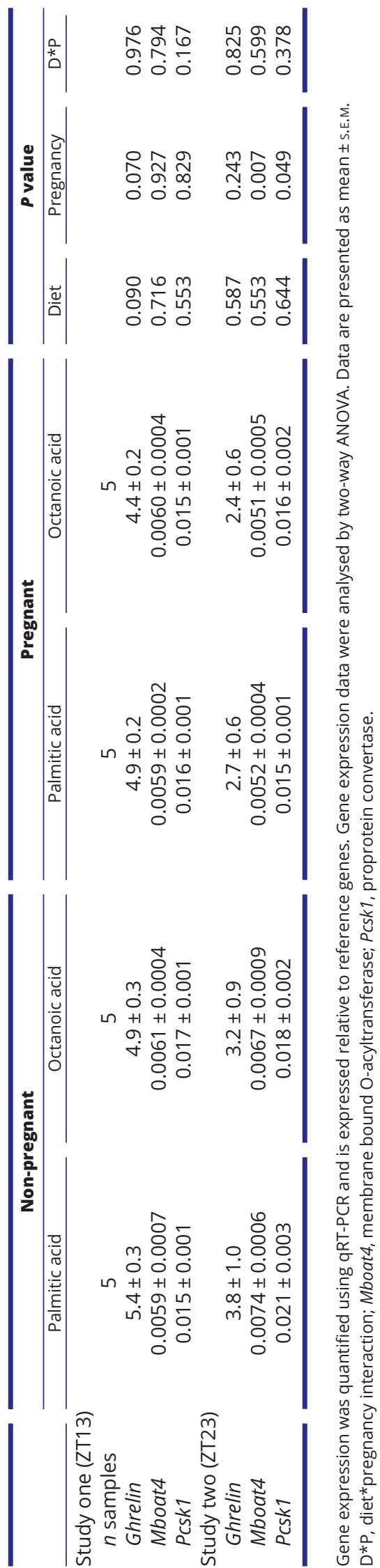

https://joe.bioscientifica.com a chance finding and not likely to reflect diet-specific outcomes. An increased density of ghrelin-expressing cells is consistent with a recent report in rats, where the density of ghrelin immunopositive cells in the stomach mucosa is increased by $\sim 10 \%$ at mid-pregnancy compared to non-pregnant animals and increases by a further $\sim 30 \%$ by the day of birth (Johnson et al. 2019). We also characterised ghrelin protein expression in the murine placenta. Cytoplasmic expression was primarily localised to the labyrinth (nutrient exchange) region, while nuclear expression was evident in both labyrinth and junctional (endocrine crosstalk) regions. This is the first report of ghrelin protein localisation in the rodent placenta, and its presence is consistent with prior reports of ghrelin mRNA expression in placenta of rats and humans (Gualillo et al. 2001).

Despite greater circulating total ghrelin in pregnancy, we did not detect greater circulating acyl-ghrelin in pregnant mice, with a lower acyl:total ghrelin ratio in pregnant compared to non-pregnant mice and lower circulating acyl-ghrelin at mid-pregnancy. The decreased ratio of acyl to total ghrelin we observed in mice are broadly consistent with those of Tham and co-authors in women, who reported markedly lower maternal acylated ghrelin concentrations during pregnancy than postpartum (Tham et al. 2009). These authors suggested that lower acyl-ghrelin during human pregnancy probably reflected decreased acylation, since they found lower rather than higher activity of the key de-acylating enzyme butylcholinesterase in the pregnant group (Tham et al. 2009). We observed comparatively lower gastric mRNA expression of Mboat4 and Pcsk1 in pregnant mice compared to non-pregnant mice at ZT23. Although the acylation of ghrelin is independent of processing by PC 1/3 (Zhu et al. 2006), lower gastric gene expression of Mboat4 at ZT23 may explain the lack of subsequent increase in circulating serum acyl-ghrelin concentrations despite higher total ghrelin concentrations in pregnant compared to nonpregnant mice sampled at ZT13. Further experiments are required to determine whether the lower acyl:total ghrelin ratio reflects slower acylation or more rapid deacylation in pregnancy. Despite the lack of elevation of circulating acyl-ghrelin in pregnancy, it is possible that the higher total ghrelin seen before substantial feeding might lead to increased local ghrelin action in tissues expressing both Mboat4 and the ghrelin-receptor, such as the pancreas, placenta and hypothalamus (Yang et al. 2008, Trivedi et al. 2017). Consistent with a potential role for elevated ghrelin during pregnancy, ghrelin receptor mRNA expression increased in hypothalamus 


\section{Journal of \\ Endocrinology}

H Kaur et al.

Ghrelin-GH axis in murine

pregnancy
A

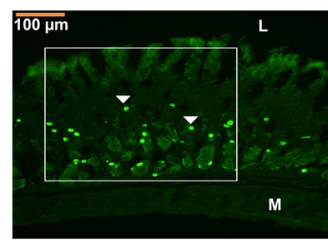

$\mathrm{B}$

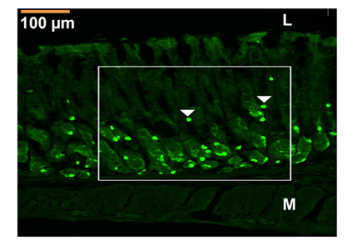

C
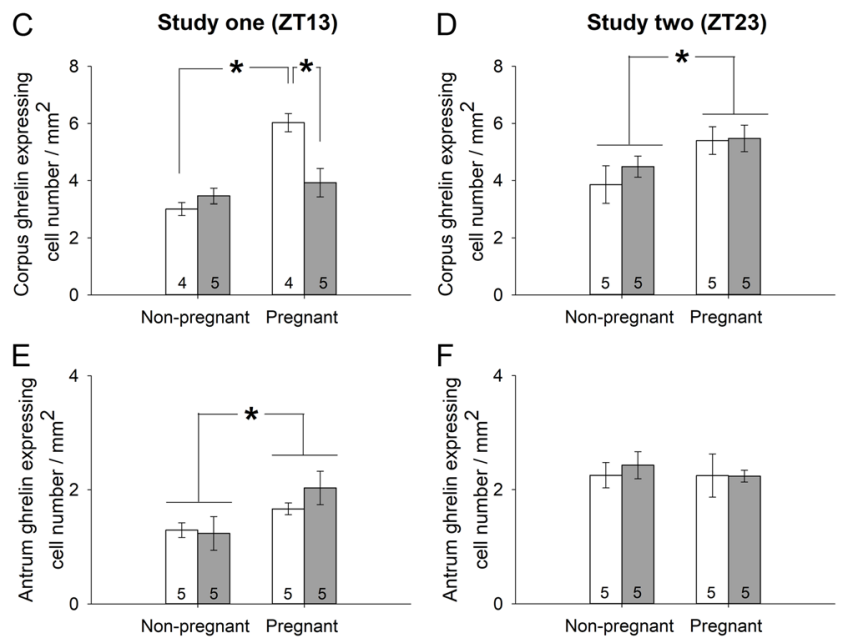

Figure 4

Immunohistochemistry for ghrelin-positive cells in the corpus of non-pregnant (A) and pregnant (B) mice. Arrows indicate ghrelin-positive cells, $\mathrm{L}$ and $\mathrm{M}$ indicate lumen and mucosal regions, respectively, scale bar $=100 \mu \mathrm{m}$. Effects of pregnancy and diet on the density of ghrelinpositive cells in the corpus ( $C$ and $D$ ) and antrum ( $E$ and $F$ ) regions of the stomach in mice fed palmitic acid diet (white bars) or octanoic acid diet (grey bars). Samples were collected at ZT13 (study one, C and E) or ZT23 (study two, D and F), in mice at GD17.5 or age-matched controls. Data were analysed by two-way ANOVA and are presented as mean \pm S.E.M. Animal numbers are indicated by numerals within bars. A full colour version of this figure is available at https://doi.org/10.1530/JOE-20-0072.

and pituitary during rat pregnancy (Szczepankiewicz et al. 2010). It is also possible that non-acylated ghrelin has a functional role in pregnancy, since growing evidence suggests that des-acyl ghrelin has GHSR1a independent roles in energy and glucose metabolism (Thompson et al. 2004, Zhang et al. 2008, Trivedi et al. 2017). We did not measure des-acyl ghrelin in the present study, but posttest meal concentrations of des-acyl (but not acyl) ghrelin were higher in women with gestational diabetes during late pregnancy and postpartum compared to normal pregnant women (Tham et al. 2009), suggesting it either regulates or responds to maternal metabolism.

Contrary to our hypothesis, dietary supplementation with octanoic acid did not alter circulating GH or ghrelin concentrations regardless of whether the mice had a full or empty stomach. Although we were able to confirm the presence of octanoic acid in our supplemented diet, we were not able to confirm its presence in the circulation, despite the fact that abundance of other circulating fatty acids were altered in response to the experimental diets. Similarly, Lemarié and co-authors could not detect C8 fatty acids in rat plasma in response to C8-supplementation with 0,8 or $21 \%$ of total fatty acids (Lemarie et al. 2015). This could possibly be due to rapid gastrointestinal hydrolysis and absorption of medium chain-fatty acids, specific transport through the portal vein and rapid beta-oxidation in the liver (Bach \& Babayan 1982). The lack of increase in acyl-ghrelin was surprising given that previous studies in mice found increased stomach acylghrelin in male mice using similar dose regimens used in the present study (Nishi et al. 2005). Furthermore, dietary supplementation with octanoic acid increased circulating acyl-ghrelin concentrations in studies conducted in humans, mice and cattle (Ashitani et al. 2009, Kirchner et al. 2009, Fukumori et al. 2013). However, in other studies, dietary supplementation with octanoic acid increased stomach acyl-ghrelin of mice (Nishi et al. 2005) and stomach octanoic acid content in rats (Lemarie et al. 2015) without any changes in circulating acyl-ghrelin secretion. Interestingly, dietary supplementation with medium chain triglycerides (MCT) increased circulating acyl-ghrelin in humans and pigs of both sexes and circulating growth hormone concentrations in pigs

Table 5 Placental ghrelin and Mboat4 mRNA expression.

\begin{tabular}{|c|c|c|c|}
\hline & Palmitic acid & Octanoic acid & P value \\
\hline \multicolumn{4}{|c|}{ Study one (ZT13) } \\
\hline n samples & 5 & 5 & \\
\hline Ghrelin & $0.0021 \pm 0.0001$ & $0.0023 \pm 0.0001$ & 0.258 \\
\hline Mboat4 & $0.0007 \pm 0.0002$ & $0.0011 \pm 0.0003$ & 0.292 \\
\hline \multicolumn{4}{|c|}{ Study two (ZT23) } \\
\hline$n$ samples & 5 & 6 & \\
\hline Ghrelin & $0.0022 \pm 0.0001$ & $0.0023 \pm 0.0002$ & 0.922 \\
\hline Mboat4 & $0.0021 \pm 0.0005$ & $0.0013 \pm 0.0004$ & 0.216 \\
\hline
\end{tabular}

Gene expression was quantified using qRT-PCR and is expressed relative to reference genes. Gene expression data were analysed by one-way ANOVA. Data are presented as mean \pm S.E.M.

Mboat4, membrane bound O-acyltransferase.

https://joe.bioscientifica.com https://doi.org/10.1530/JOE-20-0072
(C) 2020 Society for Endocrinology Published by Bioscientifica Ltd. Printed in Great Britain 


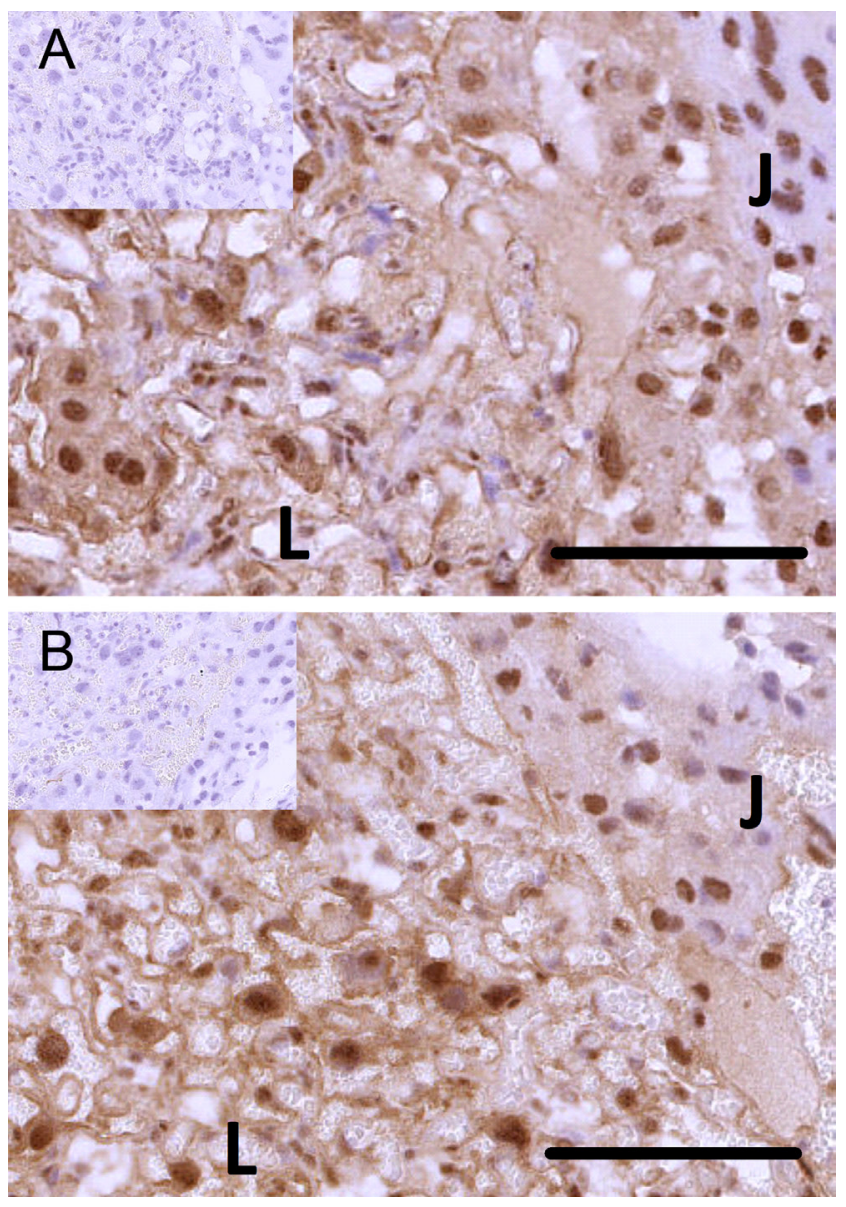

Figure 5

Immunohistochemistry for ghrelin localisation in GD17.5 murine placentas from dams fed palmitic acid (A) and octanoic acid (B) diet. $L$ and $\mathrm{J}$ indicate labyrinthine and junctional zones, respectively. Scale bar = $100 \mu \mathrm{m}$. A full colour version of this figure is available at https://doi. org/10.1530/JOE-20-0072.

(Miller et al. 2016, Kawai et al. 2017), suggesting a possible alternate dietary approach to increase circulating acylghrelin abundance. In addition, we did not see any differences in circulating $\mathrm{GH}$ patterns in response to diet. Although the current study utilised the established method of characterising patterns of pulsatile $\mathrm{GH}$ secretion in mice (Steyn et al. 2011), it was necessary to exclude data from two pregnant animals where pulsatile $\mathrm{GH}$ secretion was lost, indicative of an acute response. Pulsatile GH secretion was evident in the majority of mice, indicating that the acclimatisation and sampling protocol were mostly successful in preventing stress responses (Steyn et al. 2012). Loss of GH secretion in two pregnant mice but no non-pregnant mice on the present study, and from one late pregnant mouse and no non-, early- or midpregnant mice in our previous study (Gatford et al. 2017), suggests that pregnancy may increase susceptibility to handling-induced stress, despite extensive acclimatisation. Together with the need for consistency in the estrous cycle stage of non-pregnant mice, this resulted in a limited sampling size for GH measurements. Therefore, we cannot exclude the possibility of a diet effect on GH based only on the present study. Maternal and fetal weights did not differ with diet, which was not unexpected given that we did not anticipate any restriction of fetal growth in this model of normal pregnancy. Although mice ate both experimental diets readily, we cannot exclude the possibility that food intake may differ between diets and suggest this should be measured in subsequent studies. Future studies may find it beneficial to adapt a dietary approach based on dietary supplementation with medium chain triglycerides containing up to $65-75 \%$ of octanoic acid, which has been shown to increase circulating levels of acyl-ghrelin as well as average plasma GH levels in pigs (Miller et al. 2016).

Overall, increased total and basal GH during murine pregnancy does not appear to be regulated by maternal circulating acyl-ghrelin. Maternal total ghrelin secretion in pregnancy may follow an altered diurnal pattern, possibly due to the pregnancy-associated changes in nutrient demand and energy intake. A higher number of gastric ghrelin-expressing cells in pregnant mice may explain the time-dependent higher concentrations of circulating total ghrelin compared to non-pregnant mice. Interestingly, despite elevated total ghrelin, acylghrelin concentrations were not elevated in pregnancy or by dietary supplementation with octanoic acid at the concentrations used in the present study. Our results confirm upregulation of the GH-ghrelin axis in pregnancy, but the mechanisms underlying increases in circulating $\mathrm{GH}$ in murine pregnancy remain to be explained.

\section{Declaration of interest}

The authors declare that there is no conflict of interest that could be perceived as prejudicing the impartiality of the research reported.

\section{Funding}

This study was supported by funding from the Channel 7 Children's Research Foundation (project ID 171401). H K is supported by an Australian Government Research Training Program PhD scholarship. B S M is supported by a Career Development Award (APP:1038009). C T R is supported by the Lloyd Cox Professorial Research Fellowship from University of Adelaide.

\section{Authors contribution statement}

$H$ K, B S M, A J P, C T R and K L G conceived and designed the experiments. H K, B S M, P S S, A J P, H L, M N S, G S C, L H, R L W, J D V, C T R and K L G 
were involved in the acquisition of data. $\mathrm{HK}, \mathrm{BS} \mathrm{M}, \mathrm{A} J \mathrm{P}, \mathrm{HL}, \mathrm{L} \mathrm{H}, \mathrm{J} \mathrm{DV}$ and $\mathrm{K} \mathrm{LG}$ analysed and interpreted the data. $\mathrm{HK}$ and $\mathrm{KL}$ G drafted the article. $H$ K, B S M, A J P, H L, L H, R L W, C C, C T R and K L G critically revised the article. All authors approved the final version of the manuscript and agreed to be accountable for all aspects of the work.

\section{Acknowledgements}

The authors thank Laboratory Animal Services at the University of Adelaide for providing excellent animal care.

\section{References}

Arvat E, Maccario M, Di Vito L, Broglio F, Benso A, Gottero C, Papotti M, Muccioli G, Dieguez C, Casanueva FF, et al. 2001 Endocrine activities of ghrelin, a natural growth hormone secretagogue (GHS), in humans: comparison and interactions with hexarelin, a nonnatural peptidyl GHS, and GH-Releasing hormone. Journal of Clinical Endocrinology and Metabolism 86 1169-1174. (https://doi.org/10.1210/jcem.86.3.7314)

Ashitani J-i, Matsumoto N \& Nakazato M 2009 Effect of octanoic acid-rich formula on plasma ghrelin levels in cachectic patients with chronic respiratory disease. Nutrition Journal 825 . (https://doi. org/10.1186/1475-2891-8-25)

Bach AC \& Babayan VK 1982 Medium-chain triglycerides: an update. American Journal of Clinical Nutrition 36 950-962. (https://doi. org/10.1093/ajcn/36.5.950)

Bake T, Murphy M, Morgan DGA \& Mercer JG 2014 Large, bingetype meals of high fat diet change feeding behaviour and entrain food anticipatory activity in mice. Appetite 77 62-73. (https://doi. org/10.1016/j.appet.2014.02.020)

Caligioni CS 2009 Assessing reproductive status/stages in mice. Current Protocols in Neuroscience $\mathbf{4 8}$ Appendix 4I. (https://doi. org/10.1002/0471142301.nsa04is48)

Callahan HS, Cummings DE, Pepe MS, Breen PA, Matthys CC \& Weigle DS 2004 Postprandial suppression of plasma ghrelin level is proportional to ingested caloric load but does not predict intermeal interval in humans. Journal of Clinical Endocrinology and Metabolism 89 1319-1324. (https://doi.org/10.1210/jc.2003-031267)

Catalano PM, Tyzbir ED, Roman NM, Amini SB \& Sims EAH 1991 Longitudinal changes in insulin release and insulin resistance in nonobese pregnant women. American Journal of Obstetrics and Gynecology 165 1667-1672. (https://doi.org/10.1016/00029378(91)90012-g)

Clendinnen BG \& Eayrs JT 1961 The anatomical and physiological effects of prenatally administered somatotrophin on cerebral development in rats. Journal of Endocrinology 22 183-193. (https://doi.org/10.1677/ joe.0.0220183)

Cummings DE, Purnell JQ, Frayo RS, Schmidova K, Wisse BE \& Weigle DS 2001 A preprandial rise in plasma ghrelin levels suggests a role in meal initiation in humans. Diabetes 50 1714-1719. (https://doi. org/10.2337/diabetes.50.8.1714)

Date Y, Kojima M, Hosoda H, Sawaguchi A, Mondal MS, Suganuma T, Matsukura S, Kangawa K \& Nakazato M 2000 Ghrelin, a novel growth hormone-releasing acylated peptide, is synthesized in a distinct endocrine cell type in the gastrointestinal tracts of rats and humans. Endocrinology 141 4255-4261. (https://doi.org/10.1210/ endo.141.11.7757)

de Boo HA, Eremia SC, Bloomfield FH, Oliver MH \& Harding JE 2008 Treatment of intrauterine growth restriction with maternal growth hormone supplementation in sheep. American Journal of Obstetrics and Gynecology 199 e551-e559. (https://doi.org/10.1016/j. ajog.2008.04.035)
Delhanty PJ, Huisman M, Julien M, Mouchain K, Brune P, Themmen AP, Abribat T \& Lely AJ 2015 The acylated (AG) to unacylated (UAG) ghrelin ratio in esterase inhibitor-treated blood is higher than previously described. Clinical Endocrinology 82 142-146. (https://doi. org/10.1111/cen.12489)

El-Kasti MM, Christian HC, Huerta-Ocampo I, Stolbrink M, Gill S, Houston PA, Davies JS, Chilcott J, Hill N, Matthews DR, et al. 2008 The pregnancy-induced increase in baseline circulating growth hormone in rats is not induced by ghrelin. Journal of Neuroendocrinology 20 309-322. (https://doi.org/10.1111/j.13652826.2008.01650.x)

Eriksson L, Frankenne F, Eden S, Hennen G \& Schoultz B 1989 Growth hormone 24-h serum profiles during pregnancy - lack of pulsatility for the secretion of the placental variant. British Journal of Obstetrics and Gynaecology 96 949-953. (https://doi. org/10.1111/j.1471-0528.1989.tb03352.x)

Fuglsang J, Skjærbæk C, Espelund U, Frystyk J, Fisker S, Flyvbjerg A \& Ovesen P 2005 Ghrelin and its relationship to growth hormones during normal pregnancy. Clinical Endocrinology 62 554-559. (https:// doi.org/10.1111/j.1365-2265.2005.02257.x)

Fukumori R, Sugino T, Shingu H, Moriya N, Kobayashi H, Hasegawa Y, Kojima M, Kangawa K, Obitsu T, Kushibiki S, et al. 2013 Ingestion of medium chain fatty acids by lactating dairy cows increases concentrations of plasma ghrelin. Domestic Animal Endocrinology 45 216-223. (https://doi.org/10.1016/j.domaniend.2013.09.005)

Gargosky SE, Owens JA, Walton PE, Owens PC, Wallace JC \& Ballard FJ 1991 Administration of insulin-like growth factor-I, but not growth hormone, increases maternal weight gain in late pregnancy without affecting fetal or placental growth. Journal of Endocrinology 130 395-400. (https://doi.org/10.1677/joe.0.1300395)

Gatford KL, Owens JA, Campbell RG, Boyce JM, Grant PA, De Blasio MJ \& Owens PC 2000 Treatment of underfed pigs with GH throughout the second quarter of pregnancy increases fetal growth. Journal of Endocrinology 166 227-234. (https://doi.org/10.1677/joe.0.1660227)

Gatford KL, Boyce JM, Blackmore K, Smits RJ, Campbell RG \& Owens PC 2004 Long-term, but not short-term, treatment with somatotropin during pregnancy in underfed pigs increases the body size of progeny at birth. Journal of Animal Science 82 93-101. (https://doi. org/10.2527/2004.82193x)

Gatford KL, Muhlhausler BS, Huang L, Sim PS-L, Roberts CT, Velhuis JD \& Chen C 2017 Rising maternal circulating GH during murine pregnancy suggests placental regulation. Endocrine Connections 6 260-266. (https://doi.org/10.1530/EC-17-0032)

Gnanapavan S, Kola B, Bustin SA, Morris DG, McGee P, Fairclough P, Bhattacharya S, Carpenter R, Grossman AB \& Korbonits M 2002 The tissue distribution of the mRNA of ghrelin and subtypes of its receptor, GHS-R, in humans. Journal of Clinical Endocrinology and Metabolism 87 2988. (https://doi.org/10.1210/jcem.87.6.8739)

González-Domínguez MI, Lazo-de-la-Vega-Monroy ML, Zaina S, Sabanero M, Daza-Benítez L, Malacara JM \& Barbosa-Sabanero G 2016 Association of cord blood des-acyl ghrelin with birth weight, and placental GHS-R1 receptor expression in SGA, AGA, and LGA newborns. Endocrine 53 182-191. (https://doi.org/10.1007/s12020015-0833-1)

Gualillo O, Caminos JE, Blanco M, Garcìa-Caballero T, Kojima M, Kangawa K, Dieguez C \& Casanueva FF 2001 Ghrelin, a novel placental-derived hormone. Endocrinology 142 788-794. (https://doi. org/10.1210/endo.142.2.7987)

Gutierrez JA, Solenberg PJ, Perkins DR, Willency JA, Knierman MD, Jin Z, Witcher DR, Luo S, Onyia JE \& Hale JE 2008 Ghrelin octanoylation mediated by an orphan lipid transferase. PNAS 105 6320-6325 (https://doi.org/10.1073/pnas.0800708105)

Harding JE, Evans PC \& Gluckman PD 1997 Maternal growth hormone treatment increases placental diffusion capacity but not fetal or placental growth in sheep. Endocrinology 138 5352-5358. (https://doi. org/10.1210/endo.138.12.5584) https://joe.bioscientifica.com

https://doi.org/10.1530/JOE-20-0072 (c) 2020 Society for Endocrinology Published by Bioscientifica Ltd. Printed in Great Britain 
Hassouna R, Zizzari P, Tomasetto C, Veldhuis JD, Fiquet O, Labarthe A, Cognet J, Steyn F, Chen C, Epelbaum J, et al. 2014 An early reduction in GH peak amplitude in preproghrelin-deficient male mice has a minor impact on linear growth. Endocrinology 155 3561-3571. (https://doi.org/10.1210/en.2014-1126)

Johnson ML, Saffrey MJ \& Taylor VJ 2019 Gastrointestinal capacity, gut hormones and appetite change during rat pregnancy and lactation. Reproduction 157 431-443. (https://doi.org/10.1530/REP-18-0414)

Jørgensen KD, Svendsen O, Agergaard N \& Skydsgaard K 1991 Effect of human growth hormone on the reproduction of female rats. Pharmacology and Toxicology 68 14-20. (https://doi. org/10.1111/j.1600-0773.1991.tb01201.x)

Kanakri K, Carragher J, Hughes R, Muhlhausler B \& Gibson R 2017 A reduced cost strategy for enriching chicken meat with omega-3 long chain polyunsaturated fatty acids using dietary flaxseed oil. British Poultry Science 58 283-289. (https://doi.org/10.1080/00071668.2017. 1293798)

Kawai K, Nakashima M, Kojima M, Yamashita S, Takakura S, Shimizu M, Kubo C \& Sudo N 2017 Ghrelin activation and neuropeptide Y elevation in response to medium chain triglyceride administration in anorexia nervosa patients. Clinical Nutrition ESPEN 17 100-104. (https://doi.org/10.1016/j.clnesp.2016.10.001)

Kentish SJ, Frisby CL, Kennaway DJ, Wittert GA \& Page AJ 2013 Circadian variation in gastric vagal afferent mechanosensitivity. Journal of Neuroscience 33 19238-19242. (https://doi.org/10.1523/ JNEUROSCI.3846-13.2013)

Kentish SJ, Vincent AD, Kennaway DJ, Wittert GA \& Page AJ 2016 High-fat diet-induced obesity ablates gastric vagal afferent circadian rhythms. Journal of Neuroscience 36 3199-3207. (https://doi. org/10.1523/JNEUROSCI.2710-15.2016)

Kirchner H, Gutierrez JA, Solenberg PJ, Pfluger PT, Czyzyk TA, Willency JA, Schürmann A, Joost HG, Jandacek RJ, Hale JE, et al. 2009 GOAT links dietary lipids with the endocrine control of energy balance. Nature Medicine 15 741-745. (https://doi.org/10.1038/ nm.1997)

Kojima M, Hosoda H, Date Y, Nakazato M, Matsuo H \& Kangawa K 1999 Ghrelin is a growth-hormone-releasing acylated peptide from stomach. Nature $\mathbf{4 0 2}$ 656-660. (https://doi.org/10.1038/45230)

Ladyman SR, Augustine RA \& Grattan DR 2010 Hormone interactions regulating energy balance during pregnancy. Journal of Neuroendocrinology 22 805-817. (https://doi.org/10.1111/j.13652826.2010.02017.x)

Ladyman SR, Carter KM \& Grattan DR 2018 Energy homeostasis and running wheel activity during pregnancy in the mouse. Physiology and Behavior 194 83-94. (https://doi.org/10.1016/j. physbeh.2018.05.002)

Lager S \& Powell TL 2012 Regulation of nutrient transport across the placenta. Journal of Pregnancy 2012 179827. (https://doi. org/10.1155/2012/179827)

Lemarie F, Beauchamp E, Dayot S, Duby C, Legrand P \& Rioux V 2015 Dietary caprylic acid (C8:0) does not increase plasma acylated ghrelin but decreases plasma unacylated ghrelin in the rat. PLOS ONE $\mathbf{1 0}$ e0133600. (https://doi.org/10.1371/journal.pone.0133600)

Li H, Kentish SJ, Wittert GA \& Page AJ 2018 Apelin modulates murine gastric vagal afferent mechanosensitivity. Physiology and Behavior 194 466-473. (https://doi.org/10.1016/j.physbeh.2018.06.039)

Liao S, Vickers MH, Stanley JL, Ponnampalam AP, Baker PN \& Perry JK 2016 The placental variant of human growth hormone reduces maternal insulin sensitivity in a dose-dependent manner in C57BL/6J mice. Endocrinology 157 1175-1186. (https://doi.org/10.1210/en.20151718)

Liu G, Mühlhäusler BS \& Gibson RA 2014 A method for long term stabilisation of long chain polyunsaturated fatty acids in dried blood spots and its clinical application. Prostaglandins, Leukotrienes, and Essential Fatty Acids 91 251-260. (https://doi.org/10.1016/j. plefa.2014.09.009)
Mano-Otagiri A, Ohata H, Iwasaki-Sekino A, Nemoto T \& Shibasaki T 2009 Ghrelin suppresses noradrenaline release in the brown adipose tissue of rats. Journal of Endocrinology 201 341-349. (https://doi. org/10.1677/JOE-08-0374)

Miller DW, Prosser Z, Chee EY, Hansen CF, Dunshea FR, Mullan BP \& Pluske JR 2016 Dietary stimulation of the endogenous somatotropic axis in weaner and grower-finisher pigs using medium chain triglycerides and cysteamine hydrochloride. Journal of Animal Science and Biotechnology 7 61. (https://doi.org/10.1186/s40104-016-0121-9)

Murray SA, Morgan JL, Kane C, Sharma Y, Heffner CS, Lake J \& Donahue LR 2010 Mouse gestation length is genetically determined. PLOS ONE 5 e12418. (https://doi.org/10.1371/journal.pone.0012418)

Nakahara K, Nakagawa M, Baba Y, Sato M, Toshinai K, Date Y, Nakazato M, Kojima M, Miyazato M, Kaiya H, et al. 2006 Maternal ghrelin plays an important role in rat fetal development during pregnancy. Endocrinology 147 1333-1342. (https://doi.org/10.1210/ en.2005-0708)

Nakazato M, Murakami N, Date Y, Kojima M, Matsuo H, Kangawa K \& Matsukura S $2001 \mathrm{~A}$ role for ghrelin in the central regulation of feeding. Nature 409 194-198. (https://doi.org/10.1038/35051587)

National Health and Medical Research Council of Australia 2013 Australian Code Of Practice for the Care and Use of Animals for Scientific Purposes. 8th edn. Canberra, Australia: Australian Government Publishing Service.

Neary NM, Druce MR, Small CJ \& Bloom SR 2006 Acylated ghrelin stimulates food intake in the fed and fasted states but desacylated ghrelin has no effect. Gut $\mathbf{5 5} 135$.

Newbern D \& Freemark M 2011 Placental hormones and the control of maternal metabolism and fetal growth. Current Opinion in Endocrinology, Diabetes, and Obesity 18 409-416. (https://doi. org/10.1097/MED.0b013e32834c800d)

Nishi Y, Hiejima H, Hosoda H, Kaiya H, Mori K, Fukue Y, Yanase T, Nawata H, Kangawa K \& Kojima M 2005 Ingested medium-chain fatty acids are directly utilized for the acyl modification of ghrelin. Endocrinology 146 2255-2264. (https://doi.org/10.1210/en.2004-0695)

Nonoshita A, Nishi Y, Takushima S, Oshima M, Hosoda H, Kangawa K, Kojima M, Mifune H, Tanaka E, Hori D, et al. 2010 Dynamics of placental ghrelin production and its receptor expression in a Dahl salt-sensitive rat model of intrauterine growth restriction. Placenta 31 358-364. (https://doi.org/10.1016/j.placenta.2010.02.013)

Palik E, Baranyi E, Melczer Z, Audikovszky M, Szöcs A, Winkler G \& Cseh K 2007 Elevated serum acylated (biologically active) ghrelin and resistin levels associate with pregnancy-induced weight gain and insulin resistance. Diabetes Research and Clinical Practice 76 351-357. (https://doi.org/10.1016/j.diabres.2006.09.005)

Papper Z, Jameson NM, Romero R, Weckle AL, Mittal P, Benirschke K, Santolaya-Forgas J, Uddin M, Haig D, Goodman M, et al. 2009a Ancient origin of placental expression in the growth hormone genes of anthropoid primates. PNAS 106 17083-17088. (https://doi. org/10.1073/pnas.0908377106)

Pringle KG \& Roberts CT 2007 New light on early post-implantation pregnancy in the mouse: roles for insulin-like growth factor-II (IGF-II)? Placenta 28 286-297. (https://doi.org/10.1016/j. placenta.2006.04.006)

Roberts CT, White CA, Wiemer NG, Ramsay A \& Robertson SA 2003 Altered placental development in interleukin-10 null mutant mice. Placenta 24 (Supplement A) S94-S99. (https://doi.org/10.1053/ plac.2002.0949)

Saunders A, Terry LC, Audet J, Brazeau P \& Martin JB 1976 Dynamic studies of growth hormone and prolactin secretion in the female rat. Neuroendocrinology 21 193-203. (https://doi.org/10.1159/000122525)

Shibata K, Hosoda H, Kojima M, Kangawa K, Makino Y, Makino I, Kawarabayashi T, Futagami K \& Gomita Y 2004 Regulation of ghrelin secretion during pregnancy and lactation in the rat: possible involvement of hypothalamus. Peptides 25 279-287. (https://doi. org/10.1016/j.peptides.2004.01.011) 
Solano ME, Thiele K, Kowal MK \& Arck PC 2016 Identification of suitable reference genes in the mouse placenta. Placenta 39 7-15. (https://doi. org/10.1016/j.placenta.2015.12.017)

Spencer GSG, Robinson GM, Berry CJ \& Dobbie PM 1994 Alteration of maternal growth hormone levels during pregnancy influences both fetal and postnatal growth in rats. Biology of the Neonate 66 112-118. (https://doi.org/10.1159/000244098)

Sterle JA, Cantley TC, Lamberson WR, Lucy MC, Gerrard DE, Matteri RL \& Day BN 1995 Effects of recombinant porcine somatotropin on placental size, fetal growth, and IGF-I and IGF-II concentrations in pigs. Journal of Animal Science 73 2980-2985. (https://doi. org/10.2527/1995.73102980x)

Steyn FJ, Huang L, Ngo ST, Leong JW, Tan HY, Xie TY, Parlow AF, Veldhuis JD, Waters MJ \& Chen C 2011 Development of a method for the determination of pulsatile growth hormone secretion in mice. Endocrinology 152 3165-3171. (https://doi.org/10.1210/en.2011-0253)

Steyn FJ, Leong JW, Huang L, Tan HY, Xie TY, Nelson C, Waters MJ, Veldhuis JD, Epelbaum J \& Chen C 2012 GH does not modulate the early fasting-induced release of free fatty acids in mice. Endocrinology 153 273-282. (https://doi.org/10.1210/en.2011-1681)

Szczepankiewicz D, Skrzypski M, Pruszynska-Oszmalek E, Zimmermann D, Andralojc K, Kaczmarek, Wojciechowicz T, Sassek M \& Nowak KW 2010 Importance of ghrelin in hypothalamus-pituitary axis on growth hormone release during normal pregnancy in the rat. Journal of Physiology and Pharmacology 61 443-449.

Teixeira PDS, Couto GC, Furigo IC, List EO, Kopchick JJ \& Donato JJ 2019 Central growth hormone action regulates metabolism during pregnancy. American Journal of Physiology: Endocrinology and Metabolism 317 E925-E940. (https://doi.org/10.1152/ajpendo.00229.2019)

Tham E, Liu J, Innis S, Thompson D, Gaylinn BD, Bogarin R, Haim A, Thorner MO \& Chanoine JP 2009 Acylated ghrelin concentrations are markedly decreased during pregnancy in mothers with and without gestational diabetes: relationship with cholinesterase. American Journal of Physiology: Endocrinology and Metabolism 296 E1093-E1100. (https://doi.org/10.1152/ajpendo.90866.2008)

Thompson NM, Gill DA, Davies R, Loveridge N, Houston PA, Robinson IC \& Wells T 2004 Ghrelin and des-octanoyl ghrelin promote adipogenesis directly in vivo by a mechanism independent of the type 1a growth hormone secretagogue receptor. Endocrinology 145 234-242. (https://doi.org/10.1210/en.2003-0899)

Trivedi A, Babic S, Heiman M, Gibson WT \& Chanoine JP 2015 Acylated ghrelin is not required for the surge in pituitary growth hormone observed in pregnant mice. Peptides 65 29-33. (https://doi. org/10.1016/j.peptides.2015.01.005)

Trivedi A, Babic S, Heiman M, Gibson WT \& Chanoine JP 2017 Ghrelin, ghrelin o-acyltransferase, and carbohydrate metabolism during pregnancy in calorie-restricted mice. Hormone and Metabolic Research 49 64-72. (https://doi.org/10.1055/s-0042-116117)

Tschöp M, Smiley DL \& Heiman ML 2000 Ghrelin induces adiposity in rodents. Nature 407 908-913. (https://doi.org/10.1038/35038090)

Tschöp M, Wawarta R, Riepl RL, Friedrich S, Bidlingmaier M, Landgraf R \& Folwaczny C 2001 Post-prandial decrease of circulating human ghrelin levels. Journal of Endocrinological Investigation 24 RC19-RC21. (https://doi.org/10.1007/BF03351037)

Tung E, Roberts CT, Heinemann GK, De Blasio MJ, Kind KL, van Wettere WH, Owens JA \& Gatford KL 2012 Increased placental nutrient transporter expression at midgestation after maternal growth hormone treatment in pigs: a placental mechanism for increased fetal growth. Biology of Reproduction 87 126. (https://doi.org/10.1095/ biolreprod.112.100222)

Veldhuis JD, Johnson ML, Veldhuis OL, Straume M \& Pincus SM 2001 Impact of pulsatility on the ensemble orderliness (approximate entropy) of neurohormone secretion. American Journal of Physiology: Regulatory, Integrative and Comparative Physiology 281 R1975-R1985. (https://doi.org/10.1152/ajpregu.2001.281.6.R1975)

Xie TY, Ngo ST, Veldhuis JD, Jeffery PL, Chopin LK, Tschöp M, Waters MJ, Tolle V, Epelbaum J, Chen C, et al. 2015 Effect of deletion of ghrelino-acyltransferase on the pulsatile release of growth hormone in mice. Journal of Neuroendocrinology 27 872-886. (https://doi.org/10.1111/ jne.12327)

Yanagihara H, Ando H, Hayashi Y, Obi Y \& Fujimura A 2006 High-fat feeding exerts minimal effects on rhythmic mRNA expression of clock genes in mouse peripheral tissues. Chronobiology International 23 905-914. (https://doi.org/10.1080/07420520600827103)

Yang J, Brown MS, Liang G, Grishin NV \& Goldstein JL 2008 Identification of the acyltransferase that octanoylates ghrelin, an appetite-stimulating peptide hormone. Cell 132 387-396. (https:// doi.org/10.1016/j.cell.2008.01.017)

Zhang W, Chai B, Li JY, Wang H \& Mulholland MW 2008 Effect of desacyl ghrelin on adiposity and glucose metabolism. Endocrinology 149 4710-4716. (https://doi.org/10.1210/en.2008-0263)

Zhu X, Cao Y, Voodg K \& Steiner DF 2006 On the processing of proghrelin to ghrelin. Journal of Biological Chemistry $\mathbf{2 8 1}$ 38867-38870. (https://doi.org/10.1074/jbc.M607955200)

Received in final form 13 February 2020

Accepted 24 February 2020

Accepted Manuscript published online 16 March 2020 https://joe.bioscientifica.com https://doi.org/10.1530/JOE-20-0072 (c) 2020 Society for Endocrinology Published by Bioscientifica Ltd. Printed in Great Britain 